\title{
Studi Retorika Dalam Bedah Film 3 Dara Pada Tipikal Komunikator Womanizer
}

\author{
Rida Anjani, Mutiara Ayu Lestari, Wahyuni Choiriyati \\ Universitas Gunadharma
}

\begin{abstract}
Abstrak
Merujuk pada artikel Hamudi, Womanizer merupakan seorang pria yang mampu memahami apa yang diinginkan dan diharapkan oleh wanita, sinyal cinta yang dipancarkan oleh seorang wanita, serta dapat menjadi siapa saja bagi wanita itu. Studi Retorika penelitian ini membedah Film 3 Dara terkait gaya komunikasi pria metroseksual tipikal womanizer. Film 3 Dara merupakan film yang menceritakan 3 tokoh laki-laki yang memiliki karakter womanizer. Analisis komunikator tipikal womanizer dalam riset ini menggunakan teori Retorika. Retorika diartikan sebagai seni berbicara yang dipergunakan dalam proses komunikasi antar manusia. Seni berbicara ini berkaitan erat dengan konsep womanizer yaitu kategori pria yang mampu menaklukan hati para wanita dengan mudahnya namun tidak berniat untuk menjalin hubungan serius dengan lawan jenis. Orientasi womanizer hanya untuk kesenangan semata. Penelitian ini menitikberatkan pada analisis tipikal komunikator womanizer mengenai bagaimana gaya komunikasi dan strategi komunikasi yang digunakan di lingkungan sosial mereka dalam berinteraksi. Penelitian ini menggunakan pendekatan fenomenologi Alfred Schuzt dan teori Narsism yang merujuk pada Littlejohn (2009). Upaya mengungkap gaya komunikasi kategori pria metroseksual dalam film ini menempatkan paradigma konstruktivis.
\end{abstract}

Kata Kunci: Retorika, Narsism, Gaya Komunikasi, Womanizer

\section{Abstract}

Referring to Hamudi's article, Womanizer is a man who can understand well what is desired and expected by women, and can understand every signal of love emitted by a woman and can be anyone to her. The rhetorical study of this study dissected Film 3 in relation to the typical metexexual male communication style of a womanizer. Film 3 Dara is a film that tells 3 male characters who have a womanizer character. The analysis of a typical womanizer communicator in this research uses Rhetoric theory. Rhetoric is defined as the art of speech that is used in the process of communication between humans. The art of speaking is closely related to the concept of womanizer, namely the category of men who are able to conquer the hearts of women easily but do not intend to establish a serious relationship with the opposite sex. The womanizer's orientation is only for pleasure. This research focuses on the typical analysis of womanizer communicators about how communication styles and communication strategies are used in their social 
environment in interacting. This study uses Alfred Schuzt's phenomenology approach and the theory of narcissism which refers to Littlejohn (2009). The effort to uncover the communication style of the metrosexual male category in this film places a constructivist paradigm.

Keywords: Rhetoric, Narcissism, Communication Style, Womanizer.

\section{Pendahuluan}

Salah satu film yang mempresentasikan sosok kehidupan pria-pria womanizer adalah film 3 Dara. Film ini bercerita tentang tiga sahabat yaitu Affandi, Jay dan Richard dengan latar belakang berbeda namun memiliki kesamaan aitu mereka tipe pria womanizer dan kurang menghargai perempuan walaupun ketiganya memiliki pasangan. Affandi (Tora Sudiro), sudah menikah selama 20 tahun dan memiliki seorang anak perempuan yang mandiri. Jay (Adipati Dolken) sudah bertunangan namun masih menunda pernikahannya. Richard (Tanta Ginting) lebih memilih long distance relationship. Penelitian ini menitikberatkan pada analisis tipikal komunikator womanizer mengenai bagaimana gaya komunikasi dan strategi komunikasi yang digunakan di lingkungan sosial mereka dalam berinteraksi. Maka dari itu, penelitian ini dirasa penting untuk diteliti karena bisa menambah pengetahuan baru mengenai kajian terhadap gaya komunikasi seorang tipikal komunikator womanizer. Tujuan penelitian ini untuk mengetahui bagaimana gaya tipikal komunikator womanizer dalam berkomunikasi serta berinteraksi dengan orang-orang disekitarnya serta strategi komunikasi sepeti apa yang dilakukan oleh komunikator womanizer dalam mengikat para hati wanita. Setelah mengetahui bagaimana gaya komunikasi tipikal komunikator womanizer diharapkan bisa menjadi sumbangsih ilmu pengetahuan khususnya kajian komunikasi pada studi retorika.

\section{Kajian Literatur}

Konsep Womanizer

Womanizer merupakan istilah untuk seorang laki laki atau pria yang sangat baik kepada kaum perempuan. Entah dia hanya bermaksud baik atau hanya sekedar menebar pesona, yang pasti womanizer sering berhasil membuat perempuan salah tingkah dengan segala perhatiannya, dan karena kebaikannya, para womanizer memiliki banyak teman perempuan, yang tentu saja dikarenakan keberhasilannya dalam mengambil simpati mereka.

Womanizer sangat mencintai ibunya, ibunya adalah segala-galanya bagi womanizer, Kebanyakan dari womanizer termasuk laki-laki yang supel dan mudah bergaul dengan siapa saja, termasuk kaum perempuan. 


\section{Konsep Dasar Gaya Komunikasi}

Ada empat tipe dasar yang digunakan untuk menggambarkan gaya komunikasi seseorang:

1. Komunikasi Pasif

seseorang dengan komunikasi pasif ini tidak pernah membela diri sendiri, jika seorang komuniktor pasif, mereka akan mengindari untuk mengungkapkan pikiran, perasaan dan opininya. Ketika seseorang mengekspresikan perasaan sendiri dengan cara meminta maaf yang terkadang diabaikan oleh orang lain. Bahkan sebagai komunikator pasif, seseorang akan mengizinkan orang lain untuk mengambil keuntungan dengan melanggar hak-hak diri sendiri. Akibatnya, seseorang dengan tipe seperti ini akan merasa cemas, terjebak dan putus asa karena dirinya berada diluar kendali hidup. Perilaku seseorang dengan tipe ini membiarkan orang lain untuk mendominasi. Komunikator pasif ini dapat menjadi komunikator yang lebih kuat dengan menegaskan dirinya sendiri

2. Komunikasi Agresif

seseorang dengan tipe ini akan tetap mempertahankan diri sendiri secara langsunng namun terkadang berperilaku tidak pantas. Komunikasi verbalnya terkesan melecehkan dan melanggar hak orang lain. Pribadi agresif juga berasal dari rassa rendah diri yang dilampiaskan dalam bentuk dominasi kekuaaan. Sebagai komunikator agresif, seseorang mencoba untuk mendominasi dan mengancam, sering mengkritik dan menyalahkan lemahnya orang lain untuk mendapat kekuasaan. Bahasa tubuhnya terlihat sombong dan cepat marah kalau tidak sesuai dengan keinginan. Sebagai hasilnya, si Agresif ini akan dijauhi orang lain dan merasa lepas kendali.

3. Komunikasi Pasif-Agresif

Tipe ini tidak berhubungan langsung dengan masalah. Mereka tampaknya tidak memiliki masalah dengan orang lain, sedangkan secara tidak langsung mengekspresikan kemarahan Anda dan frustasi. Sebagai komunikator Pasif-Agresif, seseorang ini menggunakan sarkasme, penolakan dan bahassa tubuh yang membingungkan. Komunikator ini, menghindari konfrontasi langsung, namun berupaya untuk mendapatkan bahkan melalui manipulasi. Mereka sering merasa tidak berdaya dan kesal. Mereka sering mengatakan "ya" ketika mereka benar-benar ingin mengatakan "tidak". Pasif-Agresif komunikator sering sarkatis dan berbicara tidak baik tentang orang-orang dibelakang punggung mereka.

4. Komuniaksi Tegas

Seorang komunikator dikatakan kuat jika memiliki tipe ini. Jika seorang komunikator tegas, maka mereka akan efektif menyatakan pikiran dan perasaan secara jelas dan hirmat. Mereka menangani masalah tanpa melanggar atau mengasingkan orang lain. Mereka cenderung memiliki sehat harga diri yang tinggi. Sebagai komunikator tegas, bahasa tubuhnya pun tenang, kontrol diri dan mendengarkan aktif.

Caroon B. Goode mengemukakan 4 gaya komunikasi, yang meliputi;

1. Gaya behavior, dimana komunikan yang memiliki gaya behavior tersebut lebih menyenangi kebebasan ekspresi diri

2. Gaya kognitif, orang seperti ini membutuhkan pengakuan dan pemahaman. Pemahaman mereka, orang yang berpikir serius

3. Gaya interpersonal, orang seperti ini membutuhkan apresiasi dalam komunikasi, mereka sangat menuntut kejujuran

4. Gaya afektif, orang seperti ini dinamakan juga sebagai seorang yang visioner atau bahkan juga disebut pemimpi. 


\section{Konsep Dasar Retorika}

Syafi'ie (1988: 1) menyatakan secara etimologis kata retorika berasal dari bahasa Yunani "Rhetorike" yang berarti seni kemampuan berbicara yang dimiliki oleh seseorang. Aristoteles (Syafi'ie, 1988: 1) memandang retorika sebagai "the facult of seeing in any situation the available means of persuasion". Menurut pengertian ini, Aristoteles mengartikan retorika adalah kemampuan untuk melihat perangkat alat yang tersedia untuk mempersuasi. Kemampuan melihat dalam pengertian ini ditafsirkan sebagai kemampuan untuk memilih dan menggunakan. Alat perangkat yang tersedia berupa bahasa dan segala aspeknya. Jadi, retorika menurut Aristoteles adalah kemampuan untuk memilih dan menggunakan bahasa dalam situasi tertentu secara efektif untuk mempersuasi orang lain. Persuasi dalam pengertian ini diartikan secara positif, yaitu menjadikan orang lain mengetahui, memahami dan menerima maksud yang disampaikan sebagai pesan atau isi komunikasi.

Retorika dipandang sebagai studi yang paling sentral dalam berbagai studi kemanusiaan. Oleh sebab itu, pada awalnya retorika memang diartikan sebagai kesenian untuk berbicara baik, yang dicapai berdasarkan bakat alam dan keterampilan teknis. Dewasa ini retorika diartikan sebagai kesenian untuk berbicara baik, yang dipergunakan dalam proses komunikasi antarmanusia. Dalam hal ini kesenian berbicara tersebut bukan berarti berbicara lancar tanpa adanya jalan pikiran yang jelas dan tanpa isi dari berbicara itu sendiri, melainkan suatu kemampuan untuk berbicara atau berpidato dengan singkat, jelas, padat, dan mengesankan (Hendrikus, 1991: 14).

Dari pendapat-pendapat di atas dapat disimpulkan bahwa (a) retorika merupakan ilmu yang mempelajari kepandaian berbicara di depan umum; (b) retorika merupakan bertutur secara efektif dengan menggunakan bahasa lisan maupun tulisan sebagai media atau bahan dasar dalam mengungkapkan gagasan; (c) retorika merupakan ilmu yang mempelajari untuk menyusun komposisi katakata agar bisa memberikan pesan dengan baik kepada audience. Lebih daripada itu, retorika juga sangat penting bagi kehidupan keseharian tiap manusia untuk berinteraksi dengan orang lain. Adapun dalam berkomunikasi terdapat unsur persuasi yang bertujuan untuk mengubah tingkah laku. I

\section{Ethos}

Ethos adalah komponen di dalam argumen yang menegakkan kepercayaan pendengar terhadap kompetensi sang pembicara.Etika adalah bagian filsafat yang meliputi hidup baik, menjadi orang yang baik, berbuat baik, dan menginginkan halhal yang baik dalam hidup. Belajar etika merupakan langkah terakhir dalam proses pendidikan dan pengertian akan sistem itu sebagaimana adanya dan cara kita menyesuaikan nilai-nilai dan prinsip-prinsip khusus kita (Solomon C Robert, 1987: 2). Jadi, dalam hal ini etika merupakan studi yang mempelajari tata perilaku yang 
baik dan buruk atau menentukan tingkah laku manusia dalam kehidupan. Aristotelels dan Plato (dalam Solomon C Robert, 1987: 5) menjelaskan etika berasal dari kata Yunani ethos yang berarti "sifat" atau "adat" dan ethika. Jadi, etika merupakan bagian dan pengertian dari ethos, usaha untuk mengerti tata aturan sosial yang menentukan dan membatasi tingkah laku manusia.

Dari uraian berikut dapat disimpulkan bahwa etika adalah usaha untuk mengerti tata aturan sosial dan membatasi tingkah laku kita. Etika meliputi semua tindak tanduk pribadi dan sosial yang dapat diterima, mulai dari tata aturan "sopan-santun sehari-hari" hingga pendirian yang menentukan jenis pekerjaan kita, siapa yang menjadi sahabat-sahabat kita, dan cara-cara kita berhubungan dengan keluarga dan orang lain. Moralitas merupakan bagian dari hukum etika.

Moralitas terdiri dari hukum dasar suatu masyarakat yang paling hakiki dan sangat kuat (Solomon C Robert, 1987: 7). Filsafat Eropa dan Amerika modern, "etika" kerap dipersamakan dengan "filsafat moral" dan filsuf yang belajar etika disebut "filsuf moral". Hal ini sendiri menunjukkan ethos kita dan juga menunjukan kenyataan bahwa kita cenderung bersifat majemuk dalam menghadapi persoalanpersoalan hidup yang beragam dan menentukan mana yang dapat dianggap tingkah laku pribadi dan sosial yang dapat diterima. Jadi, moralitas menjadi pusat etika dan pembicaraan prinsip-prinsip moral ada untuk merumuskan etika saja. Moral bukan keseluruhan etika, tetapi persoalan pokok dalam etika (Solomon C Robert, 1987: 7).

Rober L.Scott dalam bukunya yang berjudul “The Speaker's Reader's Concepts in Communication" menjelaskan tiga persyaratan etika yang harus diperhatikan komunikator dalam menyampaikan pesan komunikasi yaitu:

(1) bertanggung jawab dalam pemilihan unsur-unsur persuasif, menyadari kemungkinan berbuat salah; (2) berusaha mengetahui dan menyadari secara jujur akan kerugian yang timbul sebagai akibat keangkuhan dan kecurangan diri sendiri; dan (3) toleransi terhadap mereka yang tidak setuju terhadap apa yang kita sampaikan (Syafi'ie, 1988: 6).

Syafi'ie (1988: 5) menyatakan pentingnya peranan etika dan moral dalam retorika ini lebih nyata oleh karena retorika pada hakekatnya mempunyai ciri utama yaitu kebebasan dalam memilih. Komunikator mempunyai kebebasan memilih dan menentukan struktur pesan komunikasinya. Ada tiga kategori ethos yaitu:

1. Phronesis atau kemampuan dan kebijaksanaan yang berarti kepakaran dan kecedasan sang pembicara. Kecerdasan lebih kepada persoalan kebijaksanaan dan kemampuan dalam berbagi nilai atau kepercayaan antara komunikator dengan khalayaknya. Maksudnya adalah khalayak seringkali menilai "kecerdasan" komunikator dari sejauh mana mereka sepakat atau memiliki kesamaan cara pikir atau ide dengan komunikator tersebut. Komunikator yang cerdas adalah komunikator yang mampu menyesuaikan diri atau mampu membaca cara berpikir khalayaknya, untuk kemudian disesuaikan dengan cara berpikirnya.

2. Arete atau kebaikan dan kehebatan sang pembicara yang dinilai sebagai kredibilitas serta reputasinya. Hal ini biasa disebut karakter komunikator. Karakter lebih kepada citra komunikator sebagai orang yang baik dan orang yang jujur. Jika seorang komunikator mampu memiliki citra sebagai orang yang baik dan jujur, apapun kata-kata yang disampaikan dalam persuasinya maka khalayak cenderung lebih mudah untuk percaya. Begitu pula sebaliknya, jika komunikator yang bersangkutan memiliki citra yang kurang 
baik maka sebaik apapun kata-kata yang disampaikannya tidak akan dipercaya oleh khalayaknya.

3. Eunoia atau niat baik komunikator kepada audiens-nya. Unsur ini penting karena berkaitan dengan penerimaan pendengar terhadap moralitas dan integritas dari orang yang berbicara. Niat baik adalah penilaian positif yang coba ditularkan oleh komunikator kepada khalayaknya. Seorang komunikator mungkin mampu memperlihatkan kecerdasannya, menunjukkan karakter kepribadiannya, akan tetapi belum tentu mampu 'menyentuh hati' khalayaknya. Niat baik ini biasanya dapat dirasakan oleh hati khalayak.

\section{Logos}

Logos adalah isi dari argumen haruslah menggunakan argumentasi logika dan data. Karl Wallace (Syafi'ie, 1988: 4) mengatakan bahwa unsur pokok retorika adalah rasional yang baik. Tanpa adanya unsur rasional ini, pesan yang dikemukakan tidak memiliki kekuatan. Disinilah kekuatan retorika untuk menyanggah anggapan bahwa retorika hanya permainan bahasa. Aristoteles (Syafi'ie, 1988: 4) menyebutkan dalam bukunya yang berjudul "Rhetoric" menyebutkan istilah "good reason" yang dikemukakan oleh Karl Wallace itu dengan istilah "proof" (pembuktian atau alasan atau argumentasi).

Aristoteles mengemukakan bahwa "proof" itu mungkin "artistic" dan mungkin pula "inartistic". Artistic proof menurut Aristoteles di sini terdapat tiga macam, yaitu:

(a) ethical proof (pembuktian/ alasan/ argumentasi yang bersifat etis) yang menjanjikan sifat atau karakter yang baik dari pembicara untuk membangun kredibilitasnya sebagai penutur, (b) psychological proof (pembuktian/ alasan/ argumentasi yang bersifat psikologis) yang membawa auditor (pendengar/ pembaca) ke dalam suasana yang menunjang untuk menerima alasan yang dikemukakan penutur, (c) logical proof (pembuktian / alasan/ argumentasi yang bersifat logis) yang membuat kasus yang dikemukakan atau muncul untuk membuat kasus yang dikemukakan dalam peristiwa komunikasi.

\section{Pathos}

Pathos adalah sisi daya tarik emosional yang menyertai isi argumen dari sisi logos dan kompetensi komunikator dari sisi ethos. Penyampaian argumentasi dengan pathos inilah yang menguatkan unsur persuasinya. Pathos adalah penentu dari persetujuan pendengar pada pemaparan sang pembicara. Ketiga dimensi argumentasi yang berupa ethos, logos, dan pathos adalah satu kesatuan dalam segitiga retorika yang amat ampuh dalam membujuk atau seni persuasi.

\section{Konsep Dasar Narsisme}

Konsep dan istilah narsisme berawal dari sebuah mitologi Yunani kuno tentang seorang pemuda tampan yang bernama Narsisus. Pemuda ini sangat mengagumi dan jatuh cinta pada refleksi gambar dirinya. ia sangat ingin menjamah dan 
memiliki wajah yang dilihatnya dalam air, namun setiap kali ia mengulurkan tangannya untuk meraih refleksi dirinya, bayangan itu kemudian menghilang (Harmawan, 1999).

Secara istilah juga narsisme merupakan cinta kepada diri sendiri yang sangat ekstrim, paham yang menganggap bahwa dirinya sendiri sangat superior dan sangat. (Kartono, 2000: 64-65). Orang yang berperilaku narsisme cenderung menjadi sangat self-consciousness (Chaplin, 2003: 451), yakni perhatian yang sangat berlebihan pada diri sendiri dan apabila kecenderungan ini semakin gawat maka muncul Imaginary Audience dalam pikirannya. Menurut aliran psikoanalisis, narsisme ialah perhatian yang sangat berlebihan kepada diri sendiri, dan kurang atau tidak adanya perhatian kepada orang lain. Narsisme ini biasanya berlanjut sampai memasuki masa kedewasaan sebagai bentuk fiksasi (Kartono, 2000: 59).

\section{Ciri- Ciri Perilaku Narsisme}

Ada beberapa tanda-tanda atau ciri-ciri narsisme dari Diagnostics and Statistik Manual, Fourth Editions Text Revision (Rahmathia, 2012: 1-2) antara lain:

a. Pengidap narsisme juga yakin kalau dirinya unik dan istimewa, serta berpikiran bahwa tidak ada yang bisa menyaingi dirinya. Dia akan merasa lebih tinggi statusnya serta lebih cantik atau ganteng dibandingkan dengan yang lain.

b. Orang narsisme selalu ingin dipuji dan diperhatikan. Mereka kurang peka terhadap kebutuhan orang lain, karena yang ada dalam pikirannya adalah dirinya sendiri.

c. Orang narsisme sangat sensitif terhadap kritikan, kritikan yang kecil bisa berarti besar bagi mereka, dan tidak mau disalahkan.

d. Orang narsisme membutuhkan pengakuan dari orang lain demi memompa rasa percaya dirinya. Inilah rahasia terbesar orang narsisme. Sedangkan menurut Barlow dan Durand (2006: 212)

Selain ciri-ciri yang di atas, narsisme juga memiliki ciri-ciri lain diantaranya sebagai berikut:

a. Kurang memiliki empati

b. Suka foto selfie

c. Bersikap arogan dengan memakai aksesoris yang berlebihan, seperti gelang, kalung, antinganting, dll. Mempunyai fantasi-fantasi tentang kesuksesan, kekuasaan, kecerdasan, kecantikan, atau cinta ideal yang tanpa batas.

\section{Faktor-Faktor Penyebab Perilaku Narsisme}

Penyebab pasti gangguan atau perilaku narsisme tidak diketahui. Para peneliti mengidentifikasi faktorfaktor perkembangan masa anak-anak dan sikap orangtua yang mungkin mendukung terjadinya gangguan kepribadian narsisme antara lain:

a. Temperamen yang sangat sensitif sejak lahir.

b. Pujian dan penilaian yang berlebihan dari orang tua.

c. Penilaian orangtua sebagai tujuan untuk mengatur harga diri mereka.

d. Sanjungan yang berlebihan yang tidak pernah seimbang dengan kenyataan timbal balik. 
e. Pemberian perhatian yang tidak terduga dari orang tua.

f. Penyiksaan yang terlalu pada waktu kecil.

g. Membanggakan penampilan dan bakat orangtua (Barlow dan Durand, 2006: 212).

Menurut Kohut dan Kernberg (1978) mengemukakan lebih jauh bahwa kelainan kepribadian narsistik lebih mungkin berkembang jika orang tua lalai, menghilangkan nilai, atau tidak berempati kepada anak; individu ini akan terus menerus mencari penegasan dari sebuah pengidealan dan perasaan megah terhadap diri. Dari uraian tersebut bahwa faktor penyebab dari perilaku narsisme adalah temperamen yang sangat sensitif sejak lahir, pujian dan penilaian yang berlebihan dari orang tua. Adanya kemungkinan faktor lain yaitu faktor lingkungan diantaranya berharap mendapatkan pujian, sering selfie, lingkungan pergaulan, dan sosial media.

\section{Metode Penelitian}

Pendekatan yang akan digunakan dalam penelitian ini adalah studi deskriptif kualitatif. Penelitian ini termasuk jenis penelitian kualitatif, di mana data dan temuan disajikan dalam bentuk uraian atau deskripsi kata-kata, bukan diuji atau dianalisis dengan angka-angka statistik atau matematika. Obyek dikaji melalui penelusuran pustaka, observasi dan pemanfaatan dokumentasi tertulis, arsip atau rekaman pidato dari para retor ulung. Data dikumpulkan melalui beberapa teknik pengumpulan data, yakni:

1. Kajian Pustaka. Hal ini dilakukan dengan memperbanyak sumber referensi dan bahan pustaka, memungkinkan untuk terkumpul dan teridentifikasinya lebih banyak teori tentang retorika.

2. Observasi, untuk mengamati film 3 Dara. Teknik observasi lazim digunakan untuk menggali data dari sumber data yang berupa peristiwa, tempat atau lokasi, dan benda, serta rekaman gambar (Sutopo, 2002: 28). Dalam menjaga reliabilitas observasi dilakukan beberapa kali.

3. Dokumentasi dalam bentuk rekaman audio visual dapat diunduh melalui sumber internet (YouTube).

Data yang dikumpulkan dianalisis dengan menggunakan analisis interaktif. Teknik analisis yang dipergunakan dalam penelitian ini adalah Model Analisis Interaktif. Tiga komponen pokok analisis (reduksi data, sajian data dan penarikan simpulan) aktivitasnya dapat dilakukan dengan cara interaksi, baik antar komponennya, maupun dengan proses pengumpulan data, dalam proses yang berbentuk siklus. (Sutopo, 2002: 35). Untuk menjamin dan mengembangkan validitas data, digunakan teknik trianggulasi data/sumber yaitu mengumpulkan data sejenis dari beberapa sumber data yang berbeda, dan trianggulasi peneliti, yaitu mendiskusikan data yang diperoleh dengan beberapa orang yang cukup memahami penelitian. Penggunaan triangulasi data/sumber 
seperti ini, diharapkan semakin meningkatkan kesahihan atau validitasnya (Harahap, 2003: 50).

Peneliti menggunakan paradigma konstruktivis, merupakan paradigma dimana kebenaran suatu realitas sosial dilihat sebagai hasil konstruksi sosial, dan kebenaran suatu realitas sosial bersifat relatif. Paradigma konstruktivisme ini berada dalam perspektif interpretivisme (penafsiran) yang terbagi dalam tiga jenis, yaitu interaksi simbolik, fenomenologis dan hermeneutik.

Dalam konsep kajian komunikasi, teori konstruksi sosial bisa disebut berada diantara teori fakta sosial dan defenisi sosial (Eriyanto 2004:13). Paradigma konstruktivisme yang ditelusuri dari pemikiran Weber, menilai perilaku manusia secara fundamental berbeda dengan perilaku alam, karena manusia bertindak sebagai agen yang mengkonstruksi dalam realitas sosial mereka, baik itu melalui pemberian makna maupun pemahaman perilaku menurut Weber, menerangkan bahwa substansi bentuk kehidupan di masyarakat tidak hanya dilihat dari penilaian objektif saja, melainkan dilihat dari tindakan perorang yang timbul dari alasan-alasan subjektif. Weber juga melihat bahwa tiap individu akan memberikan pengaruh dalam masyarakatnya. Paradigma konstruktivis dipengaruhi oleh perspektif interaksi simbolis dan perspektif strukturan fungsional.

\section{Hasil Penelitian Dan Pembahasan}

Film 3 Dara merupakan film yang bercerita tentang tiga sahabat yaitu Affandi, Jay dan Richard dengan latar belakang berbeda namun memiliki kesamaan aitu mereka tipe pria womanizer dan kurang menghargai perempuan walaupun ketiganya memiliki pasangan. Affandi (Tora Sudiro), sudah menikah selama 20 tahun dan memiliki seorang istri yang kurang diberikan perhatian dan cenderung sering mengintimidasi. Jay (Adipati Dolken) sudah bertunangan namun masih menunda pernikahannya. Richard (Tanta Ginting) lebih memilih long distance relationship dan memiliki beberapa teman kencan.

Gaya komunikasi yang dilakukan oleh tokoh-tokoh pada film 3 Dara Berbeda-beda namun mereka bertiga dikategorikan sebagai pria-pria dengan tipikal womanizer yang memiliki kharisma yang kuat dalam memikat hati wanita. Namun, jika dilihat dari sudut pandang komunikasi sangatlah menarik. Penelitian ini bisa mengungkapkan bagaimana gaya seorang womanizer saat berkomunikasi dengan para wanita. Kajian komunikasi yang paling dekat untuk melihat gaya komunikasi seseorang adalah studi retorika. Retorika diartikan sebagai seni berbicara yang dipergunakan dalam proses komunikasi antar manusia. Seni berbicara ini berkaitan erat dengan konsep womanizer yaitu kategori pria yang mampu menaklukan hati para wanita dengan mudahnya. 


\begin{tabular}{|c|c|c|}
\hline No & Scene dan Tokoh & Analisis \\
\hline 1 & & $\begin{array}{l}\text { Scene ini memeperlihatkan bahwa pria-pria deng } \\
\text { womanizer memiliki kharisma yang sangat lua } \\
\text { dalam menebarkan pesonanya. Hal ini bisa dilih } \\
\text { cara mereka berpakaian dan bergaul. Biasanya } \\
\text { sosok pria yang memiliki kehidupan menengah } \\
\text { Tipe pria womanizer juga bisa dikatakan narsis. } \\
\text { dengan ciri-ciri narsisme dari Diagnostics and S } \\
\text { Manual, Fourth Editions Text Revision. } 3 \text { pria t } \\
\text { menganggap diri mereka unik, istimewa, tidak ad } \\
\text { menandingi dirinya serta selalu ingin diperhatikan }\end{array}$ \\
\hline 2 & & $\begin{array}{l}\text { Selaras dengan penjelasan konsep womanizer. Pa } \\
\text { di film } 3 \text { Dara ini cenderung sering menon } \\
\text { kelebihan serta kekuasaan mereka dan meng, } \\
\text { kaum perempuan adalah kamu yang rendah dan } \\
\text { dijadikan alat pemuas kebutuhan mereka. penjela } \\
\text { sesuai dengan salah satu scene dalam film } \\
\text { Dimana mereka bertiga sedang berada di } \\
\text { diskotik dan salah satu diantaranya mengajak } \\
\text { untuk menemani mereka selain itu juga } \\
\text { mengolok-olok wanita itu karena memilki suar } \\
\text { aneh. }\end{array}$ \\
\hline 3. & AFFANDI (TORA SUDIRO) & $\begin{array}{l}\text { Berdasarkan konsep womanizer para pria memili } \\
\text { penyayang dan sejatinya tidak ingin menyaki } \\
\text { perempuan namun dalam film ini. Aspek bukti } \\
\text { yang seharusnya lebih dominan digunakan } \\
\text { womanizer adalah pathos yaitu daya tarik em } \\
\text { dan banyak menggunakan metphora } \\
\text { berkomunikasi sebaliknya tokoh Affandi } \\
\text { mengutamakan logika atau logos dimana dia } \\
\text { berfikir logis dan mengesampikan ethos atau } \\
\text { ketika berbicara dengan istrinya atau pere } \\
\text { lainnya. Gaya komunikasi yang diguakan } \\
\text { cenderung gaya komunikasi behavior dan k } \\
\text { dimana komunikan yang memiliki gaya be } \\
\text { tersebut lebih menyenangi kebebasan ekspresi d } \\
\text { dikatakan gaya kognitif karena affandi ini sos } \\
\text { yang galak dan serius dan membutuhkan pema } \\
\text { dari karyawan-karyawannya (Caroon B. Goode). } \\
\text { Affandi bisa digolongkan kedalam komunikator } \\
\text { karena dia kadangan merendahkan lawan bicaran } \\
\text { ini sesuai dengan salah satu scene dimana ia me } \\
\text { bawahannya dengan nada merendahkan dan perla } \\
\text { dia kepada istrinya yang tidak pernah dihargai. }\end{array}$ \\
\hline 4. & & $\begin{array}{l}\text { Jay merupakan sosok yang khrismatik dan tampa } \\
\text { sudah memiliki tunanagan namun selalu m } \\
\text { pernikhannya. Hal ini sesuai dengan tipika } \\
\text { womanizer yaitu pria yang mampu menakluka } \\
\text { para wanita dengan mudahnya namun tidak } \\
\text { untuk menjalin hubungan serius. Jay adalah oran }\end{array}$ \\
\hline
\end{tabular}




\begin{tabular}{|c|c|c|}
\hline & JAY (ADIPATI DOLKEN) & $\begin{array}{l}\text { tidak mau memiliki komitmen. Namun dia } \\
\text { menyayangi tunangannya. Aspek retoris yang me } \\
\text { pada cara berkomunikasinya adalah logos atau } \\
\text { ketika meyakinkan pasangannya namun juga } \\
\text { mengesampingkan aspek ethos dan pathos-nya. } \\
\text { jay juga bisa menghargai serta bertindak romanti } \\
\text { pasangannya. Gaya komunikasi yang dilakukan o } \\
\text { adalah gaya komunikasi Behavior yaitu } \\
\text { menyenangi kebebasan ekspresi diri dan tidal } \\
\text { diatur. Jay tergolong komunikator ynag pasif-a } \\
\text { Komunikator ini, menghindari konfrontasi lan } \\
\text { namun berupaya untuk mendapatkan bahkan n } \\
\text { manipulasi. Mereka sering merasa tidak berdas } \\
\text { kesal. Mereka sering mengatakan "ya" ketika } \\
\text { benar-benar ingin mengatakan "tidak". Pasif- } \\
\text { komunikator sering sarkatis dan berbicara tida } \\
\text { tentang orang-orang dibelakang punggung merel } \\
\text { ia sering bertengkar dengan pasangannya dan bee } \\
\text { demikian. }\end{array}$ \\
\hline 5. & RICHARD (TANTA GINTING) & $\begin{array}{l}\text { Sosok Richard bisa dikatakan sosok yang paling } \\
\text { dengan konsep Pria womanizer karena Richard mo } \\
\text { banyak teman kencan dikala ia jauh dengan pace } \\
\text { Selain itu ia juga memiliki lebih dari satu pas } \\
\text { Orientasi kehidupannya hanyalah kesenangan } \\
\text { dan tidak berniat untuk memiliki hubungan yang } \\
\text { Konsep narsisme juga sangat melekat pada } \\
\text { Richard. Ia selalu tebar pesona untuk mengikat ha } \\
\text { wanita. Namun jika dianalisis melaui aspek } \\
\text { sosok Richard lebih dominan menggunakan } \\
\text { pathos atau daya tarik emosional. Nam } \\
\text { mengesampingkan aspek ethos atau etika } \\
\text { berbicara dengan wanita. Hal ini dibuktikan disal } \\
\text { scene ketika ia sedang menggoda pelayan } \\
\text { Bahasa yang tidak sopan dan ia merasa bahwa } \\
\text { bisa melakukan apapun. bahasa yang ia gy } \\
\text { cenderung menggunakan Bahasa-bahasa } \\
\text { metapora yang sedikit berlebihan agar menim } \\
\text { kesan dramatais. Bahasa-bahasa itu ia gunakan } \\
\text { memuji para wanita dan memikat hati n } \\
\text { Komunikasi yang dilakukannya tergolong komy } \\
\text { agresif karena seseorang dengan tipe ini akan } \\
\text { mempertahankan diri sendiri secara langsunng } \\
\text { terkadang berperilaku tidak pantas. Komy } \\
\text { verbalnya terkesan melecehkan dan melangga } \\
\text { orang lain. Pribadi agresif juga berasal dari rassa } \\
\text { diri yang dilampiaskan dalam bentuk do } \\
\text { kekuasaan. }\end{array}$ \\
\hline
\end{tabular}




\section{Simpulan}

Film 3 Dara adalah film yang menceritakan pria-pria tipe womanizer yang memiliki berbagai karakter dan sifat. Penelitian ini berhasil mengidentifikasi bagaimana gaya komunikasi yang dilakukan oleh para pria womanizer dalam menaklukan hati perempuan. Serta pengelompokan tipe-tipe komunikator pada pria womanizer. Setelah dilakukan analisis komprehensip maka telah ditemukan hasil sebagai berikut:

1. Pria dengan tipe womanizer memiliki kharisma yang sangat kuat sehingga ia mampu menaklukan hati perempuan dan terkadang cenderung narsis karena beranjak dari ciri-ciri narsisme yang dikemukakan dalam Diagnostics and Statistik Manual, Fourth Editions Text Revision, pria narsis merasa bahwa dirinya berbeda dan istimewa, serta berpikiran bahwa tidak ada yang bisa menyaingi dirinya. Dia akan merasa lebih tinggi statusnya serta lebih tampan dibandingkan dengan yang lain. dalam film ini juga digambarkan bahwa mereka adalah pria-pria womanizer yang ingin selalu di puji dan diperhatikan namun tanpa memikirkan kebutuhan dan perasaan orang lain.

2. Gaya komunikasi yang digunakan oleh ketiga tokoh pada film 3 dara cenderung lebih dominan menggunakan gaya komunikasi Behavior yaitu gaya komunikasi yang lebih menyenangi kebebasan ekspresi diri namun cenderung tergolong pada komunikasi agresif dimana komunikasi yang dilakukan juga terkadang merendahkan lawan bicara khusunya pada pria womanizer ini mereka banyak mamandang rendah perempuan.

3. Retorika merupakan seni berkomunikasi yang erat kaitannya dengan para pria womanizer dimana mereka sering menggunakan kata-kata kiasan metapora untuk membuat kalimat menjadi lebih menyentuh dan memiliki makna lebih dalam namun terkesan berlebihan. Tidak heran jika para womanizer pada film 3 Dara ini mampu menaklukan hati para wanita dengan mudahnya. Disamping itu aspek bukti retoris yang digunakan oleh Pria womanizer dalam mempersuasi lawan bicara berbeda-beda. Seperti tokoh Affandi dominan menggunakan aspek logos dan mengesampingkan aspek ethos dan pathos. Tokoh Jay lebih menonjolkan aspek logos namun juga tidak mengesampingkan aspek ethos dan pathos-nya. Sedangkan tokoh Richard lebih menonjolkan aspek logos dan mengesampingkan aspek ethos karena ia cenderung merendakan wanita dengan kata-kata yang tidak sopan.

\section{Referensi}

Dori Wuwur Hendrikus. (1993). Retorika, Yogyakarta: Kanisius.

Rahmat, Jalaluddin. (1996). Retorika Modem. Bandung: Rosdakaiya. Littlejohn, Stephen W \& Karen A. Foss. (2009). Teori Komunikasi, edisi 9. Jakarta: Salemba 
Humanika Ghony, M Djunaidi \& Almanshur Fauzan. (2012). Metode Penelitian Kualitatif. Jogjakarta: Ar-Ruzz Media

Morissan.2013. Teori Komunikasi.Bogor: Ghalia Indonesia

Rajiyem. (2005). "Sejarah dan Perkembangan Retorika".

Prabowo, Setiawan Hamudi. (2009). Kenapa Harus Womanizer. Dalam http://prabowo-womanizer.blogspot.com/2009/09/kenapa-haruswomanizer.html\#comment-form

Danish. (2011). Womanizer. Dalam

http://insanelysmile.blogspot.com/2011/12/womanizer.html?m=1 